\title{
Economic and Environmental Assessment of Environmental Pollution by Construction Companies in Ukraine in the System of Environmental Management in the Post- Pandemic Period
}

\author{
Katerina Zubko ${ }^{1}$, Hanna Samus ${ }^{1}$, Olena Tsyhanenko ${ }^{1}$, Mariia Troian $^{2 *}$, and Marina Järvis ${ }^{3}$ \\ ${ }^{1}$ Konotop Institute Sumy State University, Department of Technology and Management, 41615, Av. \\ Mira, 24, Konotop, Ukraine \\ ${ }^{2}$ Sumy State Makarenko Pedagogical University, Department of Tourism, Hotel and Restaurant \\ Service, 40002, Romenska str., 87, Sumy, Ukraine \\ ${ }^{3}$ Estonian Entrepreneurship University of Applied Sciences, 11415, Suur-Sõjamäe 10a, Tallin, \\ Estonia.
}

\begin{abstract}
The study's primary purpose is to develop an assessment of the implementation of environmental measures in the system of sustainable development. The development of a comprehensive approach to cost evaluation of environmental innovations allowed to estimate the total cost of the construction project together with environmental and economic damage, choose the most optimal environmental measures for housing, agricultural or road construction, more effectively organise the management system of the construction company. The article considers the importance of making environmental managerial decisions in ensuring society's ecological and economic security. The study proved that construction as a branch of material production is one of the main driving forces of the national economy in terms of results and one of the most potent pollutants. The purpose of environmental and economic assessment of losses from the construction industry is to determine the cost-benefit ratio of the construction project in monetary terms with the mandatory comparison of results before and after the implementation of environmental measures. The analysed ecological and economic indicators of the construction industry, the relationship between the volume of construction work by type of construction products and waste generation by type of economic activity allowed to justify the need for approaches to management decisions in environmental management. The study results can help integrate the requirements for managing the impact of production factors on the ecological and economic condition of the country in order to ensure the safe use of natural resources, environmental protection and economic feasibility (profitability) of management decisions in environmental management. Keywords: environmental measures, Sustainability, evaluation of the results of environmental innovations, environmental and economic losses of the
\end{abstract}

* Corresponding author: mariia.yu.troian@gmail.com 
construction project, sustainable development management, environmental management.

\section{Introduction}

At the current post-pandemic stage, management and development of the construction industry is a strategic task in connection with its participation in the creation of fixed assets of other sectors of the economy and providing housing for the population. In recent years, Ukraine has changed environmental characteristics, including disturbing the ecological and economic balance, depleting natural resources and increasing the ecological load on the main natural components, in particular, due to the activities of construction companies. Ensuring the profitability of the construction industry, taking into account environmental requirements, requires environmental and economic justification of environmental programs and measures based on indicators of environmental and economic damage, capital and current environmental costs.

Existing methodological developments for assessing environmental and economic losses do not take into account changes in economic relations and property relations in environmental protection, which significantly underestimates the negative impact of anthropogenic activities on the environment. This determines the choice of the topic of the article and its relevance.

\section{Literature review}

Theoretical issues of economic assessment of the consequences of anthropogenic pollution of the environment were investigated in the works of O. Balatskiy, S. Rogach, L. Melnyk, L. Hens, [1-3], J. Glasson et al. [4]. Problems of ecological and economic assessment of the impact on the environment of specific sectors of the economy are devoted to the work of scientists O. Amosha, E. Khlobystov, O. Prokopenko [5-7] and others [8-12].

A systematic review of the literature in building modelling, lean construction and Sustainability is presented in the study by P. Saieg et al. [13]. As a result, it is shown that the integration of the environmental approach in the design of construction projects provides significant opportunities to reduce the economic and environmental impact of the construction industry.

The authors M. Lieder and A. Rashid, in their study [14], presents the complex structure of the Concept of Circular Economy (CE) and the practical strategy for the implementation of the restorative economy and the environment. The complex structure is a combined view of three main aspects, namely: the environment, resources and economic benefits in the productive sectors of the economy

So it is necessary to investigate the factors of efficiency, the activities of construction companies, the management of which will ensure a high level of competitiveness and economic security.

\section{Purpose and research methods}

The study's primary purpose is to develop an assessment of the implementation of environmental measures in the system of sustainable development, namely the development of a comprehensive approach to assessing the value of environmental innovations. This assessment will allow us to estimate the total cost of the construction site together with environmental and economic damage, select the most optimal environmental measures for 
residential, agricultural or road construction, and organise the management system of the construction company more effectively.

Based on the analysis of the latest information characterising the state's economic, social and environmental problems, including analytical data of public authorities, the importance of environmental management decisions in ensuring environmental and economic security of society. The study proved that construction as a branch of material production is one of the main driving forces of the national economy in terms of results and one of the most substantial pollutants. According to the analysis results, the ecological-economic indicators of the construction industry, the ratio between the volume of construction work by type of construction products and waste generation by type of economic activity were evaluated, which justified the need for approaches to decisions in environmental management.

\section{Results}

The establishment and determination of ecological and economic damage in a market economy solve the problems associated with legal and economic liability for additional costs borne by both individual economic entities and society as a whole in connection with manufactured violations of natural resources. Environment [15].

The priorities of construction companies are compliance with the principles of corporate social responsibility and prevention of environmental and economic losses, as well as making a profit. During construction, the primary sources of pollution were the construction of ditches and trenches, deforestation, soil damage, formation of construction waste dumps, operation of construction machinery and equipment, etc. (Table 1).

Table 1. Waste generation by types of economic activity for 2005-2019 in Ukraine (thousand tons) [16]

\begin{tabular}{|c|c|c|c|c|c|c|c|c|c|}
\hline \multirow[b]{2}{*}{ Year } & \multirow[b]{2}{*}{ Total } & \multicolumn{7}{|c|}{ Including } & \multirow[b]{2}{*}{$\begin{array}{l}\frac{y}{0} \\
0 \\
0 \\
0 \\
0 \\
0 \\
0\end{array}$} \\
\hline & & 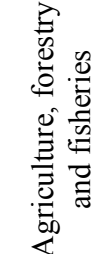 & 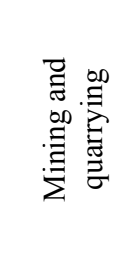 & 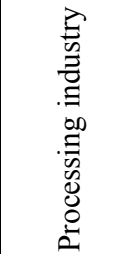 & 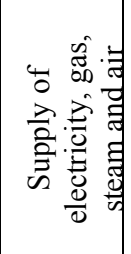 & 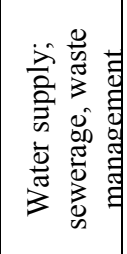 & 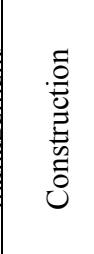 & 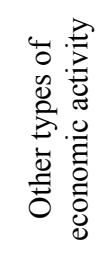 & \\
\hline 2005 & 2411,8 & 192,6 & 32,5 & 2037,0 & 10,5 & 44,7 & 59,2 & 35,3 & - \\
\hline 2006 & 2370,9 & 256,8 & 26,5 & 2010,4 & 22,0 & 33,5 & 3,9 & 17,8 & - \\
\hline 2007 & 2585,2 & 223,8 & 19,7 & 2269,0 & 9,1 & 3,2 & 3,6 & 56,8 & - \\
\hline 2008 & 2301,2 & 215,7 & 16,1 & 1989,3 & 8,8 & 2,7 & 3,1 & 65,5 & - \\
\hline 2009 & 1230,3 & 230,8 & 16,8 & 916,6 & 9,4 & 4,0 & 2,5 & 50,2 & - \\
\hline 2010 & 425914,2 & 8568,2 & 321889,8 & 75950,4 & 8641,0 & 1698,7 & 189,0 & 2254,7 & 6722,4 \\
\hline 2011 & 447641,2 & 12438,2 & 330301,9 & 79554,7 & 9901,2 & 7253,2 & 497,9 & 2517,3 & 5176,8 \\
\hline 2012 & 450726,8 & 10238,7 & 338025,0 & 78814,8 & 9812,0 & 1003,9 & 519,2 & 4343,8 & 7969,4 \\
\hline 2013 & 448117,6 & 10311,8 & 341363,2 & 74279,0 & 9346,4 & 1011,2 & 639,3 & 2140,5 & 9026,2 \\
\hline $2014^{2}$ & 355000,4 & 8451,4 & 267506,1 & 64755,8 & 5972,7 & 612,5 & 131,2 & 1256,4 & 6314,3 \\
\hline $2015^{2}$ & 312267,6 & 8736,8 & 232642,4 & 56506,3 & 6597,5 & 594,2 & 89,9 & 1047,2 & 6053,3 \\
\hline $2016^{2}$ & 295870,1 & 8715,5 & 217907,8 & 53857,9 & 7511,5 & 457,4 & 88,9 & 984,6 & 6346,5 \\
\hline $2017^{2}$ & 366054,0 & 6188,2 & 313738,2 & 32176,7 & 6191,7 & 408,7 & 493,8 & 998,7 & 5858,0 \\
\hline $2018^{2}$ & 352333,9 & 5968,1 & 301448,9 & 31523,2 & 6322,7 & 419,6 & 378,8 & 1148,7 & 5543,5 \\
\hline $2019^{2}$ & 441516,5 & 6750,5 & 390563,8 & 30751,8 & 5959,2 & 410,1 & 188,7 & 1405,8 & 5896,7 \\
\hline
\end{tabular}

${ }^{1}$ Until 2010, data on wastes of I-III hazard classes were given.

${ }^{2}$ Excluding the temporarily occupied territory of the Autonomous Republic of Crimea, the city of

Sevastopol and part of the anti-terrorist operation zone. 
As a rule, the impact of construction sites on ecosystems is complex: construction creates an additional environmental burden and causes deterioration of human health if poor quality building materials and structures are used during the construction of houses.

The world's buildings use about $40 \%$ of all primary energy consumption, $67 \%$ of electricity, $40 \%$ of raw materials and $14 \%$ of all drinking water supplies, and produce more than $35 \%$ of all carbon dioxide emissions and almost half of all municipal solid waste [17].

The volume of construction work performed by types of construction products 1 in Ukraine is presented in table 2 .

Table 2. The volume of construction work performed by types of construction products ${ }^{1}$ in Ukraine (UAH million) (Statistics, 2010-2019)

\begin{tabular}{|c|c|c|c|c|c|}
\hline \multirow{2}{*}{ Year } & \multirow{2}{*}{$\begin{array}{c}\text { Construction, } \\
\text { total }\end{array}$} & \multirow{2}{*}{ Buildings } & \multicolumn{2}{|c|}{ Including } & \multirow{2}{*}{\begin{tabular}{c}
\multirow{2}{*}{ residential } \\
non- \\
structures
\end{tabular}} \\
\hline 2010 & 42918,1 & 19659,1 & 6876,5 & 12782,6 & 23259,0 \\
\hline 2011 & 61671,7 & 26745,4 & 8137,1 & 18608,3 & 34926,3 \\
\hline 2012 & 62937,2 & 28104,8 & 8523,0 & 19581,8 & 34832,4 \\
\hline 2013 & 58586,2 & 28257,3 & 9953,1 & 18304,2 & 30328,9 \\
\hline 2014 & 51108,7 & 24856,5 & 11292,4 & 13564,1 & 26252,2 \\
\hline 2015 & 57515,0 & 28907,5 & 13908,8 & 14998,7 & 28607,5 \\
\hline 2016 & 73726,9 & 38106,4 & 18012,8 & 20093,6 & 35620,5 \\
\hline 2017 & 105682,8 & 52809,6 & 23730,0 & 29079,6 & 52873,2 \\
\hline 2018 & 141213,1 & 66791,6 & 29344,8 & 37446,8 & 74421,5 \\
\hline 2019 & 181697,9 & 83589,3 & 33208,8 & 50380,5 & 98108,6 \\
\hline
\end{tabular}

${ }^{1}$ Excluding the temporarily occupied territory of the Autonomous Republic of Crimea and the city of Sevastopol, in 2014-2019 also without part of the anti-terrorist operation zone.

Thus, quite often, already during the construction of residential and non-residential facilities, construction companies harm the environment: the terrain changes, the vegetation changes, natural plantations are replaced by artificial ones; sometimes newly introduced objects change the conditions of insolation; shading areas, changing the mode of evaporation of moisture.

The concept of rationing the impact of construction on the environment provides:

1) development of a unified system of normative values of maximum permissible levels of construction impact on land, water and atmospheric resources, as well as the generation of construction waste;

2) protection of natural resources from losses caused by the action of this impact on various components of the natural environment;

3) prevent significant functional disturbance of ecosystems due to construction's direct or indirect impact on specific environment components.

In the context of increasing construction and installation work, it is advisable to develop methodological approaches to assessing the damage from the negative impact of construction on the environment and consumers and comparing the benefits of these measures with the costs incurred by the population to restore their health.

The authors believe that it is necessary to provide the following measures to assess the environmental and economic damage due to the negative impact of construction on the population:

- assessment of the number of citizens who fall under the dangerous influence of construction;

- assessment of the probable change in the deterioration of public health;

- quantitative assessment of environmental and economic damage from changes in morbidity among the population;

- assessment of the cost of measures to prevent environmental and economic damage; 
- calculation of possible ecological and economic damage;

- analysis of alternative uses of building materials and opportunities to change construction technology.

The analysis of the possible impact of construction on the environment should include the benefits and costs of implementing any construction project. However, there are many difficulties determining the benefits and costs locally, globally, and temporally and spatially. In these cases, the benefit that can be obtained in one region (district of the city) may be accompanied by additional costs incurred in other regions (districts, cities); similarly, it is not beneficial for one region (city district) - it may be vital for another, etc.

The total value of the construction object, together with the ecological and economic damage, should be less than the total benefit from its realisation. This is a necessary condition for evaluating the decisions made in construction. In other cases, the implementation of the housing project should be cancelled.

It is advisable to evaluate the benefits using the following methods: based on rent, opportunity cost, market valuation.

Cost estimation is performed on the following elements:

1. Material costs;

2. Labor costs with accruals;

3. Depreciation deductions;

4. Expenses related to social activities;

5. Costs related to compensation or prevention of environmental and economic damage.

One of the ways to solve this problem is to develop a comprehensive approach to valuing the results of environmental innovations. The task of the environmental component is to reduce the negative impact on the environment, which requires significant capital investment in construction and thus increase the cost of production.

The economic component involves reducing the cost of production by improving the management system of construction companies, saving production resources. At the same time, the impact of the environmental component of the enterprise on its economic activity is ambiguous. Thus, the implementation of capital investments changes not only the cost of construction products but also the overall cost structure of the enterprise. Such structural changes can positively or negatively affect the efficiency of the entire enterprise. The implementation of environmental measures may lead to the receipt (loss) of an additional amount of profit for the enterprise as a whole.

The effect of environmental measures in this approach should be considered as a multiplier effect of accompanying opportunities. After all, the introduction of environmental measures involves changes in production costs, production volumes, net income, fees for using natural resources, taxes on environmental pollution and reducing the cost of paying fines for excessive pollution.

Such changes lead to a change in the cost structure of the enterprise, in which fixed costs may not change, and variables, in turn, may decrease due to cost savings on materials, wages, fuel, electricity and reduce the cost of fines for environmental pollution.

The main result of implementing environmental measures by enterprises of the construction industry is an additional economic result of implementing environmentallyfriendly innovations.

An additional accompanying result of the implementation of environmental measures by construction companies is positive or negative for enterprises changes in the cost structure or corresponding changes in the amount of operating leverage as a result of the implementation of environmental measures by construction companies, ie

$$
\Delta E_{o l}=\Delta K_{o l} \cdot P_{f p}
$$


where $\Delta E_{o l}$ - change in the amount of operating leverage;

$\Delta K_{o l}$ - change in the operating leverage ratio as a result of the implementation of environmental measures;

$P_{f p}$ - the amount of profit in the forecast period, UAH

In turn

$$
\Delta K_{o l}=K_{o l}^{1}-K_{o l}^{0}
$$

Where $K^{0}{ }_{o l}, K^{l}{ }_{o l}$ - respectively, the coefficients of operating leverage in the base and forecast periods.

When calculating the coefficient of operating leverage, it is necessary to determine the ratio of fixed and variable costs, which affects the operating leverage by the formula:

$$
K_{o l}=C_{f} / C_{v}
$$

where $K_{o l}$ is the operating leverage ratio;

$C_{f}$ - fixed costs for the volume of construction products, UAH;

$C v$ - variable costs for the volume of construction products, UAH

Therefore, the increase in operating leverage in the forecast period during the implementation of environmental measures by construction companies is determined by the formula:

$$
K_{o l}^{1}=K_{c r}^{1}-K_{o l}^{0} / K_{c r}^{0}
$$

Thus, the total effect of the implementation of environmental measures $E_{E}$ can be defined as the sum of direct and accompanying effects, UAH:

$$
E_{E}=P+\Delta E_{o l}
$$

where $P$ is the direct effect of the implementation of environmental measures

Thus, taking into account all the potential opportunities for implementing environmental innovations will assess the total economic effect of the construction industry. Only then can we talk about the economic efficiency of the construction industry.

Methodologically, the determination of ecological and economic damage from environmental pollution by a construction company should be carried out in the following sequence:

1. assessment of the level of environmental pollution;

2. identification of the relationship between the environmental pollution level and its qualitative and quantitative impact on the business entity and the territory population;

3. calculation of environmental and economic damage;

4. making changes to the construction project;

5. the formation of strategic behaviour of the construction company concerning its interaction with the environment.

Recent studies show the excess of environmental and economic damage over the environmental tax from enterprises in the construction industry, differentiated by the type of construction (Table 3).

Note that construction production's environmental and economic efficiency involves the supply of competitive goods and services that meet human needs, improve quality of life while reducing the negative impact on the environment and resource consumption throughout the life cycle of these goods and services. 
Table 3. Ecological and economic damage from construction and installation work in residential, road and agricultural construction and its relationship with the value of the environmental tax.

\begin{tabular}{|c|c|c|c|}
\hline Types of construction and installation work & $\begin{array}{l}\text { Ecological } \\
\text { economic and } \\
\text { UAH / year }\end{array}$ & $\begin{array}{l}\text { Ecological tax } \\
\text { UAH / year }\end{array}$ & $\begin{array}{l}++- \\
\%\end{array}$ \\
\hline \multicolumn{3}{|c|}{ Housing } & \\
\hline 1. Earthworks & 7505,68 & 771,56 & \\
\hline 2. Assembly and concrete works & 353,16 & 16,25 & \\
\hline 3. Brick works & 1444,16 & 87,69 & \\
\hline 4. Interior finishing works & 1681,42 & 77,69 & \\
\hline 5. Exterior finishing works & 1106,75 & 47,13 & \\
\hline Total & 12091,20 & 1000,32 & 8,2 \\
\hline \multicolumn{3}{|c|}{ Road construction } & \\
\hline 1. Earthworks & 4509,72 & 553,11 & \\
\hline $\begin{array}{l}\text { 2. Preparation for laying, laying and } \\
\text { pumping of asphalt (per } 1000 \mathrm{~m} 2 \text { ) }\end{array}$ & 8828,71 & 1680,55 & \\
\hline Total & 13338,43 & 2233,66 & 16,7 \\
\hline \multicolumn{3}{|c|}{ Agricultural construction } & \\
\hline 1. Earthworks & 2952,41 & 407,73 & \\
\hline 2. Assembly and concrete works & 686,01 & 54,73 & \\
\hline 3. Brick works & 1444,89 & 37,36 & \\
\hline 4. Exterior finishing works & 936,26 & 11,56 & \\
\hline Total & 6019,57 & 511,38 & 8,5 \\
\hline
\end{tabular}

The urgency of raising the issue of development and implementation of environmental and economic assessments is related to the need to develop the theory of economic efficiency of social production, increase the reliability of economic calculations at the level of management decisions, justification of state program approaches to solving local social and industrial problems.

Ensuring environmental and economic efficiency in the construction industry requires a systematic approach to management decisions. The optimisation of management decisions in ecology should be considered in close cooperation with nature management, ecology and economy. The subsequent management decisions are possible due to the simultaneous consideration:

a) the results of basic and applied research on the properties of the building materials themselves;

b) new technologies of secondary use of waste, aimed at increasing productivity and reducing the negative environmental impact of construction companies;

c) new organisational decisions on the certification procedure and appropriate decisionmaking criteria when planning the activities of enterprises in the construction industry.

Competitiveness of the construction enterprise is provided, including its resource component and the realisation price of habitation. Therefore, in our opinion, the most crucial thing will be to focus on maintaining a balance between the economic activity of economic entities in the construction industry and the ecological state of the environment. 
An environmentally friendly approach, based on the optimisation of measures to increase the level of environmental friendliness through innovative technologies in construction to preserve the environment and natural resources, should be used to enhance the development of the construction industry.

The results of these actions are to obtain economical, social and environmental effects. The following measures can be proposed to stimulate the introduction of ecological construction in Ukraine:

1. economic incentives from the state;

2. conducting the state ecological examination of new construction projects as, in fact, the only legitimate tool for recognising the ecological capacity of future facilities;

3. intensification of environmentally oriented investment activities;

4. development of the system of ecological education;

5. orientation of the state on resource-saving programs;

6. taking into account innovative aspects in ensuring the environmental safety of economic development;

7. formation of the market demand for environmentally friendly products.

Implementing environmental measures on a systemic and integrated basis is associated with the need to maintain a balance between production and the state of the environment.

\section{Conclusions and prospects for further research}

Sustainable development of the construction industry depends on the possibility of implementing measures to protect the environment. The economic efficiency of using natural resources is formed under the influence of minimising environmental risks that directly impact ecosystems.

Considering all the potential opportunities for implementing environmental innovations will assess the total economic effect and determine the cost structure of enterprises in the construction industry. Furthermore, one of the tools for managing construction companies should be to manage their greening.

\section{References}

1. L. Hens, L. Melnik, E. Boon, Environmental Economics (Kyiv, Naukova Dumka, 1998)

2. S. Rogach, Prace z zakresu nauk spolecznych, 14 (2013)

3. L. G. Melnyk, I. Degtyarova, J. Economics of Ukraine, 5, 75-83 (2011) (in Ukrainian)

4. J. Glasson, R. Therivel, Introduction to Environmental Impact Assessment (Routledge, 2019), https://doi.org/10.4324/9780429470738

5. O. I. Amosha, Man and the environment: economic problems of ecological safety of production (Institute of Industrial Economics, Kyiv, Scientific Opinion, 2002) (in Ukrainian)

6. L.O. Dobryanska, L.V. Zharova, E.V. Khlobistov, Strategic potential of ecological safety: technology of economic growth (Lviv, Ukrainian bestseller, 2012) (in Ukrainian)

7. O. Prokopenko, I. Marekha, MIND, 1, https://mindjournal.wseh.pl/sites/default/files/article/0916/framing ecological values in the global natural resource economics.pdf

8. K. Zubko, Economy and society, 9, 6826-832 (2017), URL: http://economyandsociety.in.ua/journal/9 ukr/9 2017.pdf (in Ukrainian)

9. S.Z. Vesperis, K.Yu. Zubko, G.I. Samus, Priazovsky Economic Bulletin, 1 (18) (2020) URL: http://pev.kpu.zp.ua/vypusk-18 (in Ukrainian)

10. M. D. Domashenko, O. V. Panchenko, M. Yu. Troyan, T. Yu Makarenko. The International

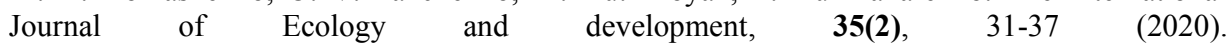
http://www.ceser.in/ceserp/index.php/ijed/article/view/6450

11. M. Yu. Troian, S.M. Frolov, Marketing and Management of Innovation, 3 (2), 125-134 (2011), URL: https://mmi.fem.sumdu.edu.ua/journals/2011/3 2/125-134 (in Ukrainian) 
12. L. Hens, L. Melnyk, O. Matsenko, O. Chygryn, and C.C. Gonzales, Marketing and Management of Innovations, 3, 272-284. http://doi.org/10.21272/mmi.2019.3-21, (2019)

13. P. Saieg, E. D. Sotelino, D. Nascimento, R. G. Gusmão Caiado, Journal of Cleaner Production, 174, 788-806 (2018), https://doi.org/10.1016/j.jclepro.2017.11.030

14. Michael Lieder, Amir Rashid, Journal of Cleaner Production, 115, 36-51 (2016), https://doi.org/10.1016/j.jclepro.2015.12.042

15. M.Kyslyy, Bulletin of SSU, Series "Economics", 1(2), 43-50 (2007) (in Russian)

16. State Statistic Service of Ukraine, http://www.ukrstat.gov.ua/

17. Z. A. Gaevskaya, Yu. S. Lazareva, A. N. Lazarev, Young scientist, 16(96) (2015) https://moluch.ru/archive/96/21620/ (in Ukrainian) 